\title{
Five-A-Day Program
}

National Cancer Institute

\section{Source}

National Cancer Institute. Five-A-Day Program. NCI Thesaurus. Code C18796.

A national initiative to increase consumption of fruits and vegetables by all Americans to 5 to 9 servings a day. The program seeks to do this by increasing public awareness of the importance of eating 5 to 9 servings of fruits and veg etables every day for better health, providing consumers with specific information about how to include more servings of fruits and vegetables into their daily routines, and increasing the availability of fruits and vegetables at home, school, work, and other places where food is served. Founded in 1991 as a partnership between the National Cancer Institute $(\mathrm{NCl})$ and the Produce for Better Health Foundation, 5 A Day is the nation's largest public/private partnership for nutrition. 